\title{
How to participate in ACRL
}

\section{Information for new members and potential members.}

$\mathbf{T}_{\mathrm{o}}$

Write or call the Association of College and Research Libraries for application forms and information: ACRL Office, 50 E. Huron St., Chicago, IL 60611-2795; (312) 944-6780.

To learn about ACRL's current programs, officers, and units

Check the ALA Handbook of Organization and read College \& Research Libraries News regularly (as a member of ACRL, you will receive both publications).

To attend conference programs, ACRL Board meetings, or committee meetings

For information on time, places, and general program content, consult $C \mho R L$ News, American Libraries, and the official conference programs and schedules. For additional information, contact the ACRL office.

To attend preconferences

For information about time, place, and preconference theme, check $C \mho R L$ News and American Libraries. For additional information and registration materials, write to the ACRL office.

To take a continuing education course

To receive a course brochure, write Sandy Donnelly at the ACRL office. To register, use information published in $C \& R L$ News or in the course brochure.

\section{To establish a local chapter of ACRL}

Check the procedures listed in "Guidelines for ACRL Chapters" (available from the ACRL office). Send a petition with the signatures of at least 25 ACRL members to the ACRL office for approval by the Board of Directors.

To request a speaker in the Chapter Speakers program

Write Cathleen Bourdon at the ACRL office and specify your date and topic. Eight chapters qualify each year for a free visit from ACRL officers or staff.

To serve on ACRL's committees or to participate in ACRL's sections and discussion groups

Familiarize yourself with the work of the unitcheck the ALA Handbook of Organization for the unit's statement of responsibility, read about the work of the unit as reported in $C \triangleleft R L$ News and American Libraries, attend the meetings of the unit during ALA conferences. Submit a completed ACRL committee volunteer form (published in the October issue of C\&RL News and available at ALA conferences). Communicate your interest to the ACRL Appointments and Nominations Committee, to any of the ACRL officers, to the chair of an ACRL unit whose work interests you, or to the ACRL office.

To be a candidate for an ACRL office

Write to the ACRL Appointments and Nominations Committee or to an ACRL section nominating committee. Submit a petition to have your name added to the list of candidates.

\section{To nominate someone for an award}

Write or call Mary Ellen Davis at the ACRL office for information or nomination forms for the Academic/Research Librarian of the Year Award, Oberly Award, Doctoral Dissertation Fellowship, Samuel Lazerow Fellowship, the Miriam Dudley BI Librarian of the Year Award, the RBMS Exhibition Catalogue Award, or the Martinus Nijhoff International West European Specialist Study Grant.

To provide suggestions for new projects, services, courses, and policies

Write to the ACRL office, to any of the ACRL officers, or to the chair of a unit whose work relates to the matter. Respond to requests published in 


\section{MAN HAS ALWAYS LONGED TO}

EMBRACE THE WORLD

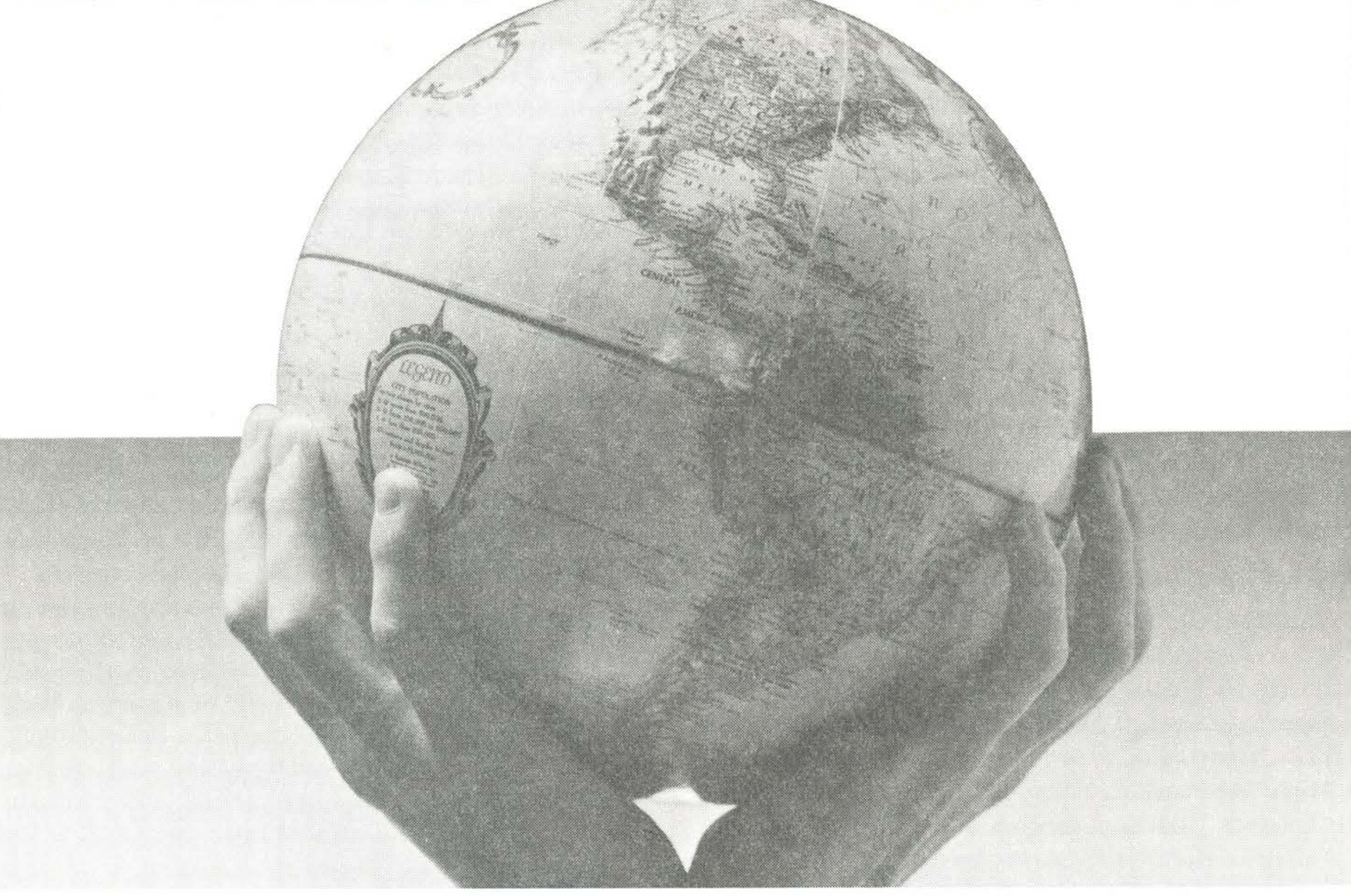

Since that dawn of October 12, 1492, when Captain Columbus' crew sighted San Salvador from the bow of the "Pinta," contact with far-off realms has moved from the fantastic to the everyday.

But as the world has shrunk, the quantity of available information has exploded, creating a whole new breed of explorer.

When you explore new worlds of information every day, you need a crew of professionals you can count on.

EBSCO has 17 offices worldwide, to help keep you in everyday contact with professional serials management services. For reliable guidance in any realm of the serials world, set your headings on EBSCO.

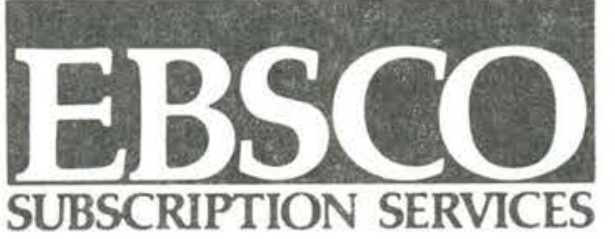

P.O. Box 1943 Birmingham, Alabama 35201 
C\&RL News for suggestions from the membership. Attend open hearings scheduled at ALA conferences. Be in touch with the Strategic Planning Task Force (Susan Klingberg, chair).

To receive information, assistance, or advice on professional problems

Contact the ACRL office, any of the ACRL officers, or the chair of an ACRL unit whose work relates to the matter.

To find information on professional library positions open

Check the classified advertising listings in $\mathrm{Col}$ lege \& Research Libraries News or American Libraries. Subscribe to the monthly Fast Job Listing Service, available from the ACRL office. Call the ACRL telephone JOBLINE, (312) 944-6795 (listings are changed every Thursday afternoon).

To obtain ACRL publications, policy statements, or CE course syllabi

For information about the availability of materials, check CURL News, ACRL's publications brochure, or the ALA Publications Checklist. You may obtain a publications brochure from the ACRL office or at ALA conferences. To order materials, write to the ACRL office.

To submit a manuscript for publication

Contact the editor of the publication. For College \& Research Libraries, send manuscripts to Charles R. Martell Jr., California State University Library, 2000 Jed Smith Drive, Sacramento, CA 95819. Instructions for authors are printed in each issue of the journal. For C $d R L$ News, send articles to George Eberhart at the ACRL office (see the guidelines published in this issue). For the $A C R L$ Publications in Librarianship series, send manuscripts to Arthur P. Young, Dean of Libraries, Uni- versity of Rhode Island, Kingston, RI 02881.

To submit news items for publication in College d Research Libraries News

Send materials to George Eberhart at the ACRL Office, 50 E. Huron St., Chicago, IL 60611-2795. Consult the guidelines for submission of news items in this issue. The deadline for receipt of news items is approximately the 26 th of each month.

\section{To subscribe to ACRL periodicals}

For a subscription to Choice, write to the Subscriptions Department, Choice, 100 Riverview Center, Middletown, CT 06457. For a subscription to $C \triangleleft R L$ or $C \& R L N e w s$, write to the Subscription Department, American Library Association, 50 E. Huron St., Chicago, IL 60611-2795.

To order works from the ACRL Publications in Librarianship series

For a listing of the works in this series, write to the ACRL office. For a list of in-print titles, check the "List of ACRL materials available," featured in this issue. To place a standing order or to order individual titles, write to the ALA Order Department, 50 E. Huron St., Chicago, IL 60611-2795. To order copies of out-of-print titles, contact University Microfilms International, 300 N. Zeeb Rd., Ann Arbor, MI 48106.

To advertise in ACRL publications

To place display ads in $C \triangleleft R L, C \downarrow R L N e w s$, or Choice, contact Art Beck, Advertising Sales Manager, Choice, 100 Riverview Center, Middletown, CT 06457. To place classified ads in C\&RL News, or job listings in the Fast Job Listing Service or the telephone JOBLINE, contact Lorraine Dorff at the ACRL Office, 50 E. Huron St. , Chicago, IL 60611 2795; (312) 944-6780, ext. 286.

\section{LITA institutes scheduled}

ALA's Library and Information Technology Association (LITA) will hold three institutes on library technology this year. Each will feature contributed papers, opportunities to meet with the speakers, and receptions.

"Telecommunications, State of the Art: A Sampler" will be held April 7-8 at the Hilton Hotel, Fort Worth, Texas. The institute will cover such areas as the requirements, advantages, and disadvantages of Local Area Networks, the use of existing facilities, protocols, the Linked Systems Project, examples of various telecommunications configurations, and how to analyze costs.

"Technology at the Library of Congress" will be held May 5-7 at the Quality Inn, Pentagon City, Arlington, Virginia. It will include such topics as an overview of the many LC systems, a technical description of the standard network interconnection, MARC developments, the optical and video disk project, the diethyl zinc preservation program, the Linked Systems Project, and many operational application systems.

"Optical Information Systems" will be held June 26-27 in New York City as a preconference institute prior to the ALA Annual Conference. The institute will cover CD ROM and video systems, software, standards, laser cards, integrating optical systems with library systems, descriptions of specific applications (such as NLM, NAL, Information Access, Newsbank, Grolier, and others), and "how they work" sessions.

For more information, contact ALA/LITA, 50 E. Huron St., Chicago, IL 60611; (312) 944-6780; ALANET ALA0080. 